\title{
BMP-4 and retinoic acid synergistically induce activation of caspase -9 and cause apoptosis of P19 embryonal carcinoma cells cultured as a monolayer
}

\author{
E Fujita ${ }^{1}$, A Soyama ${ }^{1}$, M Kawabata ${ }^{2}$ and T Momoi ${ }^{\star, 1}$ \\ ${ }^{1}$ Division of Development and Differentiation, National Institute of \\ Neuroscience, NCNP, Kodaira, Tokyo 187-8502, Japan \\ 2 Department of Biochemistry, The Cancer Institute of Japanese Foundation for \\ Cancer Research (JFCR), 1-37-1 Kami-ikebukuro, Toshima-ku, Tokyo 170- \\ 8455, Japan \\ * Corresponding author: T Momoi, Division of Development and Differentiation \\ National Institute of Neuroscience, NCNP, Kodaira, Tokyo 187-8502, Japan. \\ Tel: +481-423-46-2711 ext 5273; Fax: +481-423-46-1754; \\ E-mail: momoi@ncnp.go.jp
}

Received 18.6.99; revised 9.8.99; accepted 19.8.99

Edited by $S$ Nagata

\begin{abstract}
In monolayer cultures of P19 EC cells treated with both alltrans retinoic acid (RA) and bone morphogenetic protein (BMP)-4 (RA/BMP-4 treatment), many non-adherent apoptotic cells and activated caspase-3-positive cells were observed, but they were not observed in cells treated with RA or BMP-4 alone. Consistent with the appearance of activated caspase-3positive cells, BMP-4 and RA together induced processing of caspase-9, Ac-DEVD-MCA cleavage activity and DNA fragmentation. These three activities were observed infrequently or not at all when cells were treated with RA or BMP-4 alone. In the RA/BMP-4 treatment-induced apoptosis, caspase-9 was upstream of caspase-3 in the enzyme cascade, and the caspase- 9 to -3 step was key in the apoptotic pathway. Bcl-xL inhibited processing of caspase-9, Ac-DEVD-MCA cleavage activity and DNA fragmentation induced by RA/BMP-4 treatment. However, unlike staurosporine-induced apoptosis, cytochrome c, which activates caspase-9, was not detected in the cytosol of RA/BMP-4-treated cells. RA and BMP-4 may activate caspase-9 through an apoptotic pathway other than the Apaf-1/cytochrome c pathway. The prominent decrease of $X$-chromosome-linked inhibitory apoptosis protein (XIAP) in the cytosol may explain the activation of caspase-9 induced by RA and BMP-4 treatment.
\end{abstract}

Keywords: P19 EC cells; caspase-9; BMP-4; retinoic acid; XIAP

Abbreviations: BMP-4, bone morphogenetic protein-4; RA, alltrans retinoic acid; XIAP, X-chromosome-linked inhibitor of apoptosis protein

\section{Introduction}

During development, bone morphogenic protein (BMP)-4, a member of the TGF- $\beta$ family, induces apoptosis of cells in the interdigits $^{1}$ and of neural crest-derived cells located in the rhombomeres. ${ }^{2,3}$ Disruption of BMP-2 and -4 signaling by a dominant-negative BMP type I receptor mutation prevents interdigital apoptosis. ${ }^{4}$ Similarly, mutant mice with a targeted deletion of the retinoic acid receptor (RAR) $\alpha$ gene and one or both alleles of the RAR $\gamma$ gene show a marked decrease in the number of apoptotic cells in the interdigital necrotic zones. ${ }^{5}$ Thus, both retinoic acid and BMP signals are involved in apoptosis of cells in the interdigits.

All-trans retinoic acid (RA) induces neuroectodermal differentiation in aggregated P19 EC cells and mesoderm and endoderm differentiation in P19 EC cell monolayers. ${ }^{6}$ During RA-induced neuronal differentiation of P19 EC cells, many cells undergo cell death with the hallmarks of apoptosis, including cytoplasmic contraction and DNA fragmentation. ${ }^{7,8}$ BMP-4 alone and RA alone cause slight induction of apoptosis of P19 EC cells cultured as monolayers, but BMP-4 and RA together induce severe apoptosis of P19 EC cells. ${ }^{9,10}$ RA/BMP-4-induced apoptosis is mediated through activation of RAR $\alpha$ and $\gamma$ in P19 EC cells. ${ }^{10}$ However, little is known about the molecular mechanism by which BMP-4 and RA synergistically induce apoptosis.

Genetic studies of apoptosis in Caenorhabditis elegans have identified genes involved in apoptosis: ced-9 prevents apoptosis $^{11}$ and ced-3 and ced-4 promote apoptosis. ${ }^{12,13}$ In mammals, caspases, which are homologues of Ced-3, are involved in various types of cell death. ${ }^{14,15}$ Caspases are activated by a cascade of sequential enzymatic cleavages by other members of this family. ${ }^{16}$ During apoptosis, caspase-3, which is the last enzyme in this cascade, is activated by processing of procaspase-3 (p32) into its active forms (p20/17 and p12). ${ }^{17}$ Caspase-9, which is activated through its association with Apaf- 1 , a homologue of Ced-4 that also binds cytochrome $\mathrm{c}^{18}$ is autoprocessed into its active form, and it activates caspase-3. ${ }^{19}$

Recently, several lines of evidence have suggested that caspases are involved in BMP-mediated cell death. Caspase inhibitors prevent apoptosis of cells in the interdigits of limbs, ${ }^{20,21}$ where RA and BMP signals cause apoptosis. Using a cleavage site-directed antibody against caspase-3 (anti-p20/17), we previously demonstrated that activated caspase-3-positive cells are located in the interdigits of the limbs. ${ }^{22}$ TAK1, a member of the MAP kinase kinase kinase family that functions in the TGF- $\beta$ / BMP signaling pathway, ${ }^{23}$ induces apoptosis in Xenopus embryos. $^{24} \mathrm{Bcl}-2$, a homologue of Ced-9, blocks TAK1induced apoptosis. X-chromosome-linked inhibitor of 
apoptosis protein (XIAP), ${ }^{25}$ which can directly inhibit caspase activity, ${ }^{26}$ has been shown to bind TAB1, an activator of TAK1, and inhibit TAK1-induced apoptosis. ${ }^{27}$ Furthermore, BMP-2-induced neuronal cell death is inhibited by wide range caspase inhibitor z-VAD. ${ }^{28}$

In the present study, we demonstrate that BMP-4 and RA synergistically decrease XIAP in the cytosol of P19 EC cells cultured as monolayers and activate the caspase- 9 to -3 apoptotic pathway.

\section{Results}

We used the anti-p20/17 antibody to examine immunohistochemically whether caspase- 3 is activated when apoptosis is induced in P19 EC cells by RA- and/or BMP-4 treatment. In monolayer cultures of P19 EC cells treated for $24 \mathrm{~h}$ with RA and BMP-4 together, many non-adherent cells demonstrating cytoplasmic contraction, a hallmark of apoptosis, and many p20/17-positive cells were observed, but they were observed infrequently or not at all in the cultures incubated with RA or BMP-4 alone (Figure 1).

Consistent with the appearance of p20/17-positive cells, Ac-DEVD-MCA cleavage activity, which reflects activation of caspase-3, increased when cells were incubated with RA and BMP-4 together for $24 \mathrm{~h}$ (Figure 2A). RA (1000 nM) alone induced caspase-3 activation slightly and BMP-4 $(10 \mathrm{ng} / \mathrm{ml})$ alone did not. DNA fragmentation was also induced by RA/BMP-4-treatment and corresponded to the increase in Ac-DEVD-MCA cleavage activity (Figure 2B).

We examined the caspases upstream of caspase-3 that are activated during apoptosis induced by RA/BMP-4treatment. Caspase- 9 is one of the enzymes upstream of caspase-3. The molecular weight of mouse caspase- 9 predicted from the nucleotide sequence is $50 \mathrm{kDa}$ (nucleotide sequences have been deposited into DDBJ, Accession No. ABO19600). Only two amino acids in the peptide of mouse caspase- 9 differed from those of human caspase-9, which was used as antigen to generate anticaspase-9 (I16). When N-terminal FLAG-tagged (N-FLAG) mouse caspase- 9 was transfected into COS cells, $50 \mathrm{kDa}$ (p50) and $37 \mathrm{kDa}$ (p37) bands were detected with both antiFLAG and anti-caspase-9 (Figure 3A).

When N-FLAG mouse caspase- 9 was transfected into P19 EC cells, Ac-DEVD-MCA activity increased in a timedependent manner (Figure 3B). p50 was detected with anticaspase-9 in untreated P19 EC cells, and $30 \mathrm{kDa}$ (p30) bands as well as p50 bands were detected in P19 EC cells transfected with mouse caspase-9 (Figure 3C). However, no bands were detected with anti-FLAG because the $\mathrm{N}$ terminal region of caspase-9 is cleaved off in P19 EC cells (Fujita, unpublished data). Ac-DEVD-CHO $(10 \mu \mathrm{M})$, which completely inhibited Ac-DEVD-MCA cleavage activity, did not inhibit the processing of caspase-9 (p50) into p30 in P19 EC cells (Figure 3C).

In addition to the activation of caspase-3, generation of p30 was also induced by RA/BMP-4-treatment, and it corresponded to the increase in Ac-DEVD-MCA cleavage activity (Figure 4A). Furthermore, Ac-DEVD-CHO (1$20 \mu \mathrm{M})$ inhibited the DNA fragmentation induced by RA/ BMP-4 treatment but did not affect the processing of
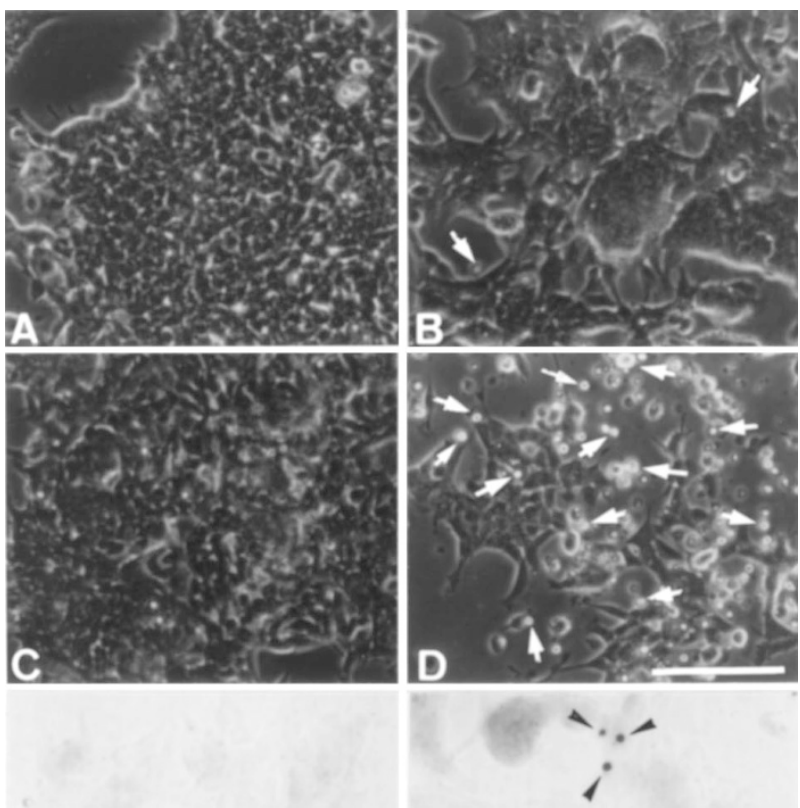

$\mathbf{E}$

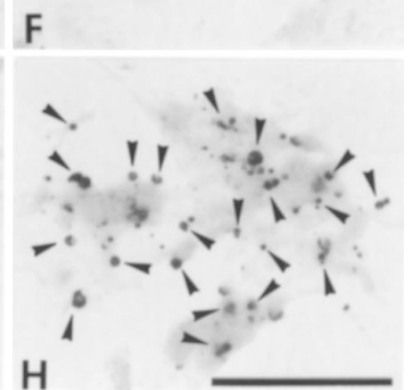

Figure 1 Appearance of apoptotic cells and activated caspase-3 (p20/17)positive cells in the P19 EC cells cultured as monolayer with RA and BMP-4 together. After P19 EC cells were treated with RA (1000 nM) and/or BMP-4 $(10 \mathrm{ng} / \mathrm{ml})$ for $24 \mathrm{~h}$, appearance of apoptotic cells and p20/17-positive cells were examined. (A-D) Photomicrographys of the cells observed under light microscope. (E-H) Immuno-cytochemical staining of activated caspase-3 (p20/17)-positive cells. (A,E) Untreated cells, (B,F) RA-treated cells, (C, G) BMP-4-treated cells, and (D,H) RA/BMP-4-treated cells. Many apoptotic cells with cytoplasmic contraction (arrows) and p20/17-positive cells (arrowheads) were detected in the RA/BMP-4-treated cells. Bars indicate $200 \mu \mathrm{m}$

caspase-9 (Figure 4B,C). Thus, caspase-9 is upstream of caspase-3 in the apoptosis pathway induced by RA/BMP-4treatment.

The synergistic effects of RA and BMP-4 on processing of caspase-9 were examined. RA (100$1000 \mathrm{nM}$ ) slightly induced processing of caspase-9 and changed Ac-DEVD-MCA cleavage activity in monolayer cultures of P19 EC cells. BMP-4 (1 ng/ml) increased AcDEVD-MCA cleavage activity, processing of caspase-9, and DNA fragmentation of P19 EC cells treated with 1$1000 \mathrm{nM}$ RA (Figure 5). RA (100 nM) in combination with BMP-4 (1 ng/ml) yielded the maximum effect on AcDEVD-MCA cleavage activity. 
A)

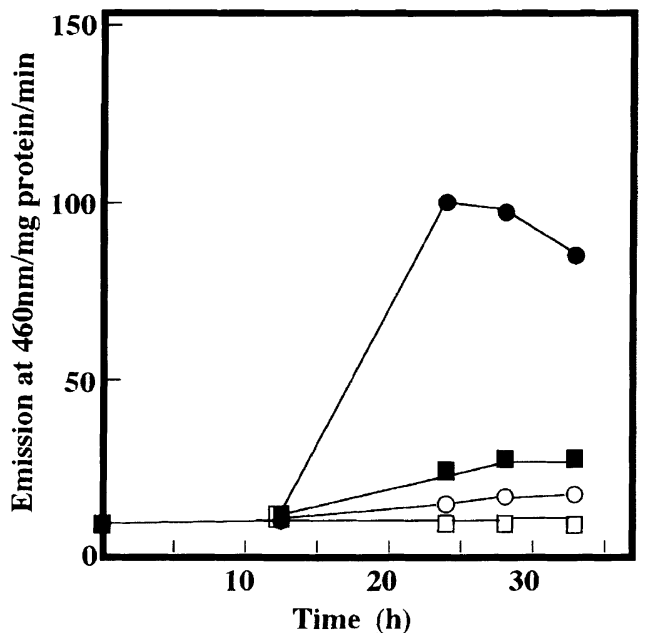

B)

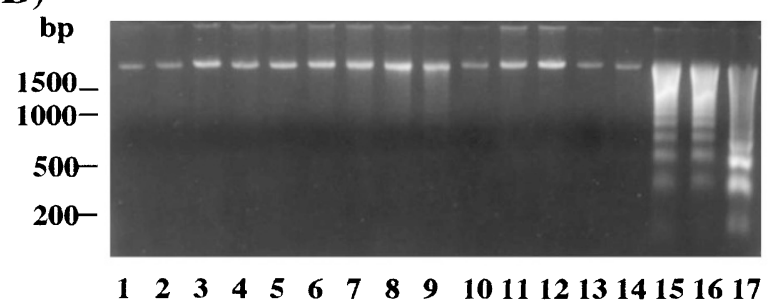

Figure 2 Time-dependent effects of RA/BMP-4 treatment on the Ac-DEVDMCA cleavage activity and DNA fragmentation. (A) Ac-DEVD-MCA cleavage activity in the untreated cells (open squares), the BMP-4 $(10 \mathrm{ng} / \mathrm{ml})-($ open circles), the RA (1000 nM)-(closed squares), and RA (1000 nM)/BMP-4 (10 ng/ $\mathrm{ml}$ )-(closed circles) treated cells. (B) DNA fragmentation of RA- and/or BMP-4treated cells. Lane 1; $0 \mathrm{~h}$, lane 2-5; untreated cells, lane 6-9; RA-treated cells, lane 10-13; BMP-4-treated cells, lane 14-17; RA and BMP-4-treated cells. Lane $1 ; 0 \mathrm{~h}$, lane $2,6,10$, and 14 ; at $12 \mathrm{~h}$, lane $3,7,11$, and 15 ; at $24 \mathrm{~h}$, lane $4,8,12$, and 16 ; at $28 \mathrm{~h}$, lane $5,9,13$, and 17 ; at $33 \mathrm{~h}$

BMP-4 $(0.1-5 \mathrm{ng} / \mathrm{ml})$ alone did not induce processing of caspase-9, change Ac-DEVD-MCA cleavage activity, or induce DNA fragmentation in the monolayer cultures of P19 EC cells. BMP-4 $(0.1-5 \mathrm{ng} / \mathrm{ml})$ enhanced these changes in a dose-dependent fashion in P19 EC cells treated with $1000 \mathrm{nM}$ RA (Figure 6). Thus, BMP-4 alone could not induce activation of caspase- 9 , but it enhanced the RAinduced activation of caspase- 9 that led to the apoptosis of P19 EC cells.

$\mathrm{Bcl}-\mathrm{xL}$, a member of the $\mathrm{Bcl}-2$ family that inhibits activation of caspase-3 through interaction with Apaf-1 and caspase-9, ${ }^{29,30}$ inhibited Ac-DEVD-MCA cleavage activity and DNA fragmentation in P19 EC cells treated with both RA (1000 nM) and BMP-4 (0.1-5 ng/ml) (Figure $7 A, B)$. Bcl-xL also inhibited processing of caspase- 9 in cells treated with RA and BMP-4.

Cytochrome $\mathrm{c}$ released from mitochondria activates caspase- 9 by association with Apaf- 1 in the cytosol. ${ }^{18}$ The levels of cytochrome $c$ and other molecules, which regulate processing of caspase- 9 , were examined in the cytosol of non-adherent apoptotic cells and adherent living cells after RA/BMP-4-treatment. The non-adherent cells showed high levels of DNA fragmentation, whereas
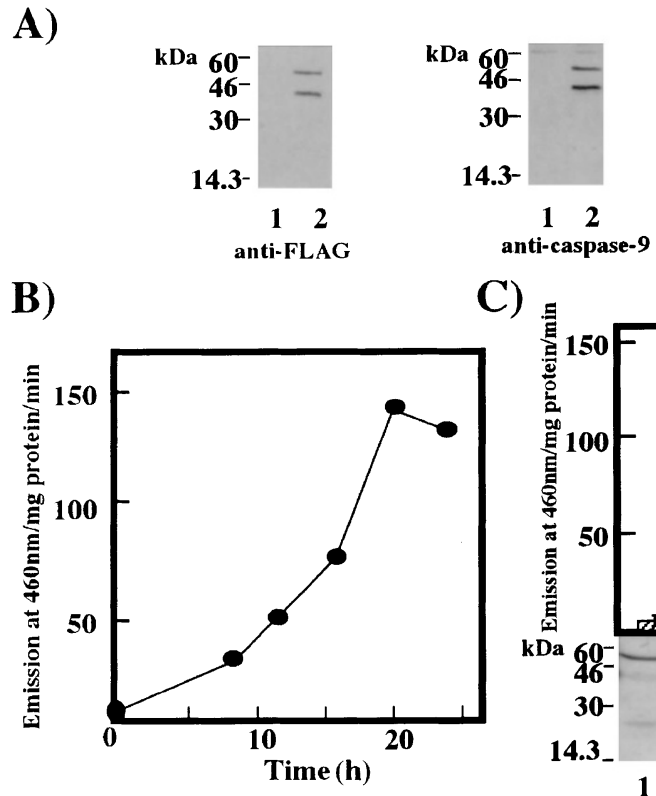

C)

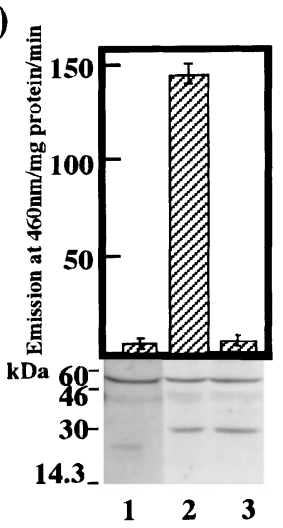

Figure 3 Autoprocessing fragment of caspase-9 inducing the activation of caspase-3. (A) The processing of caspase-9 overexpressed in COS cells. Mouse caspase-9 in N-FLAG-tagged pcDEF3 vector was transfected into COS cells. The processing fragments were detected by anti-FLAG and anticaspase-9 (I16). Lane 1; untreated COS cells, lane 2; COS cells transfected with mouse caspase-9. (B) Time-dependent Ac-DEVD-MCA cleavage activity after P19 EC cells were transfected with caspase-9 in N-FLAG-tagged pcDEF3 vector. (C) Effect of Ac-DEVD-CHO on the processing of caspase-9 (lower panel) and Ac-DEVD-MCA cleavage activity (upper panel) in P19 EC cells. P19 EC cells were transfected with caspase-9 in the presence or absence of Ac-DEVD-CHO $(10 \mu \mathrm{M})$. After $8 \mathrm{~h}$, cells were washed with the medium and further incubated with or without $10 \mu \mathrm{M}$ Ac-DEVD-CHO for $20 \mathrm{~h}$. The processing of caspase- 9 was detected by immunoblot analysis using anticaspase-9 (I16). Lane 1; vector DNA transfected cells, lane 2; caspase-9 transfected cells, lane 3 ; caspase- 9 transfected cells in the presence of AcDEVD-CHO

adherent cells did not (Figure 8A). Consistent with DNA fragmentation, Ac-DEVD-MCA cleavage activity in the cytosol of the non-adherent cells was approximately four times higher than that in the cytosol of all cells. Processing of caspase- 9 was also preferentially stimulated in the cytosol of non-adherent cells but not in the cytosol of adherent cells (Figure 8B). However, Apaf-1 and cytochrome $c$ levels in the cytosol of the non-adherent and adherent RA/BMP-4-treated cells matched those in the cytosol of untreated P19 EC cells. In contrast, XIAP was down-regulated in the cytosol of non-adherent cells but not in the cytosol of adherent cells. In the staurosporineinduced apoptotic cells, however, the level of cytochrome $c$ increased in the cytosol, whereas the levels of XIAP and Apaf-1 did not change.

\section{Discussion}

\section{Caspase cascade in the apoptosis of P19 EC cells induced by RA and BMP-4}

Caspase- 9 and caspase- 3 were activated in the apoptosis of P19 EC cells induced by RA/BMP-4-treatment (Figures 2, 4, 5 
A)
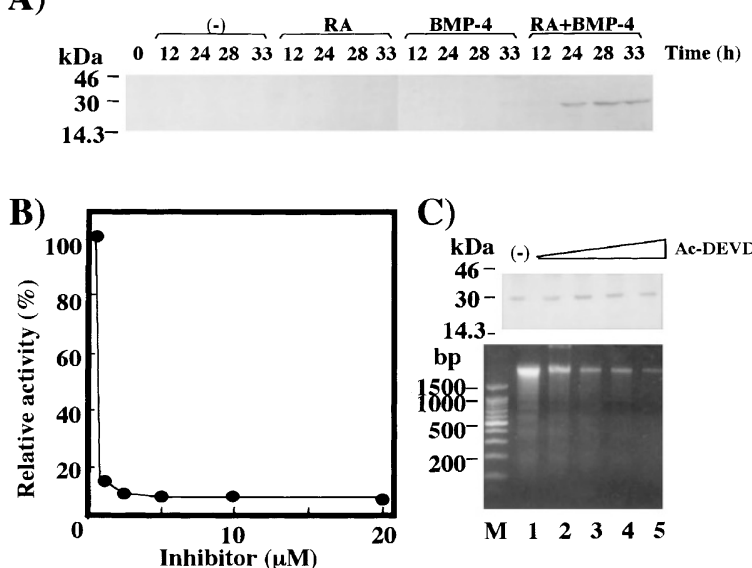

C)

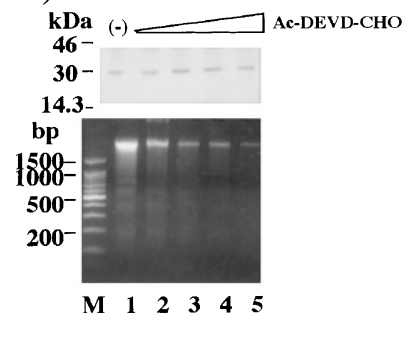

Figure 4 Caspase-9 is upstream of caspase-3 activated in the apoptosis induced by RA and BMP-4 together. (A) Activation of caspase-9 in RA- and/or BMP-4-treated cells. Processing of caspase-9 into p30 was examined by immunoblot analysis using anti-caspase-9 (I16). (B) The concentration of ACDEVD-CHO required to inhibit Ac-DEVD-MCA cleavage activity induced by RA and BMP-4 together. (C) Effect of AC-DEVD-CHO on the activation of caspase9 and DNA fragmentation induced by RA and BMP-4 together. Lane 1-5; processing fragment of caspase-9 (upper panel) and DNA fragmentation (lower panel) induced by RA and BMP-4 in the presence of Ac-DEVD-CHO at $0,1,2,5$ and $10 \mu \mathrm{M}$, respectively. M; size marker of DNA

and 6). Caspases are activated via sequential processing by other caspases. ${ }^{17}$ In the caspase cascade, caspase-9 is upstream of caspase- $33^{31-33}$ caspase-3 is not activated in caspase-9-deficient mice. However, caspase-3 also participates in a feedback amplification loop involving caspase- $9,{ }^{33}$ and the activated caspase-3 cleaves caspase-9. During apoptosis of P19 EC cells induced by RA/BMP-4-treatment, the caspase- 9 to -3 apoptotic pathway was activated (Figures 3, 4). Caspase-9 induced Ac-DEVD-MCA cleavage activity in P19 EC cells, whereas Ac-DEVD-CHO inhibited DNA fragmentation but not processing of caspase- 9 induced by RA/BMP-4-treatment. It is unlikely that the caspase-3 to -9 feedback pathway is involved in RA/BMP-4-mediated apoptosis.

We do not exclude the possibility that other caspases upstream of caspase-3 are also activated by RA/BMP-4. However, we could not detect changes in caspase-1, -6, -7, and -8 activities in RA/BMP-4-treated cells using synthetic substrates for caspases (data not shown). Inhibitors of these caspases did not prevent apoptosis or Ac-DEVDMCA cleavage activity induced by RA/BMP-4-treatment (data not shown). These results indicate that the caspase-9 to -3 pathway is the predominant pathway in the apoptosis of P19 EC cells induced by RA/BMP-4-treatment. Development of a specific inhibitor of autoprocessing of caspase9 is currently underway for further analysis.

\section{Cytochrome c release in the RA and BMP-4-treated apoptotic cells}

Bcl-xL prevented processing of caspase-9 induced by RA/ BMP-4 treatment (Figure 7). At present, the only apoptotic pathway known to activate caspase- 9 and to be regulated by
A)

B)
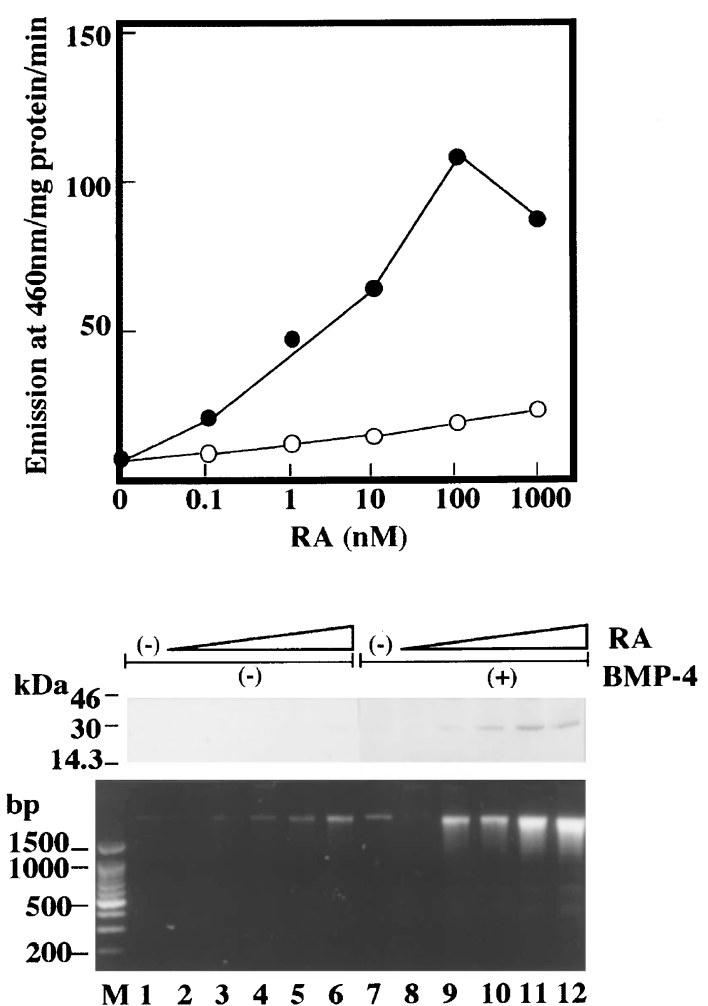

Figure 5 The RA concentration required to induce the synergistic effects on the activation of caspase-9, Ac-DEVD-MCA cleavage activity and DNA fragmentation of P19 EC cells in the cooperation with BMP-4. (A) Dosedependent effects of RA on AC-DEVD-MCA cleavage activity of P19 EC cells treated with (closed circles) or without BMP-4 $(1 \mathrm{ng} / \mathrm{ml})$ (open circles). (B) Dose-dependent effects of RA on the processing of caspase-9 (upper panel) and DNA fragmentation (lower panel). Lane 1 and 7 ; without RA, lane 2 and 8 ; with RA at $0.1 \mathrm{nM}$, lane 3 and 9; with $\mathrm{RA}$ at $1 \mathrm{nM}$, lane 4 and 10 ; with $\mathrm{RA}$ at $10 \mathrm{nM}$, lane 5 and 11 ; with RA at $100 \mathrm{nM}$, lane 6 and 12; with RA at $1000 \mathrm{nM}$. Lane 1-6; without BMP-4, lane 7-12; with BMP-4 (1 ng/ml). M; size marker of DNA

$\mathrm{Bcl}-\mathrm{XL}$ is the Apaf-1/cytochrome c-induced pathway. ${ }^{29,30} \mathrm{Bcl}-$ $\mathrm{xL}$ inhibits activation of caspase-9 through two possible mechanisms: by preventing release of cytochrome $\mathrm{c}$ from mitochondria or by forming a complex with Apaf-1 and caspase-9. However, unlike staurosporine ${ }^{34}$ RA/BMP-4 treatment did not increase cytochrome $c$ levels even in the cytosol of non-adherent apoptotic cells with high caspase-9 processing activity and Ac-DEVD-MCA cleavage activity (Figure 8), suggesting that RA and BMP-4 signals activate caspase-9 without releasing cytochrome $\mathrm{c}$ from mitochondria. Recently, an alternative pathway that activates the caspase cascade was reported. RGD peptides directly activate caspases independent of the Apaf-1/cytochrome $c$ apoptotic pathway. ${ }^{35}$ RA and BMP-4 signals may activate caspase-9 through such an alternative pathway. However, reductions in mitochondria transmembrane potentials, which accompany early apoptosis in many situations, were detected in the RA and RA/BMP-4-treated cells as well as in staurosporinetreated cells by fluorescence of the cationic lipophilic dye CMTMRos $^{34}$ (Momoi, unpublished data). We do not exclude 
A)

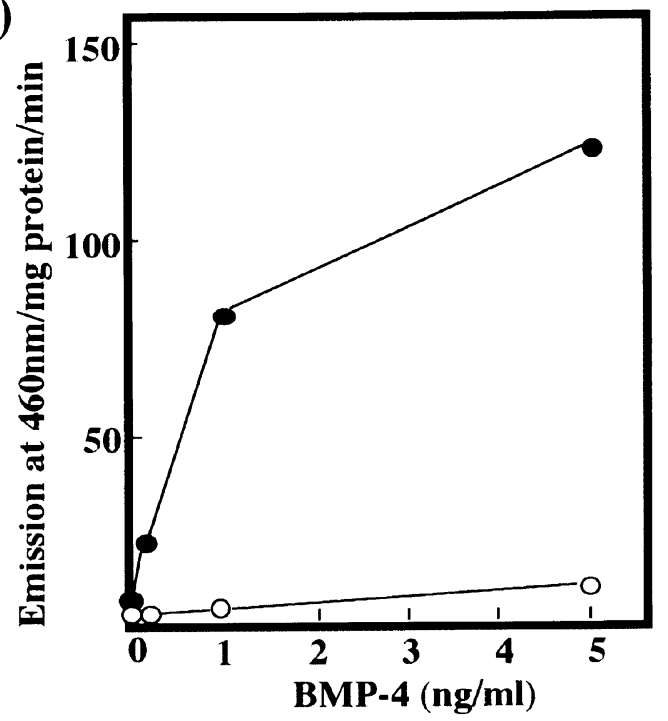

B)

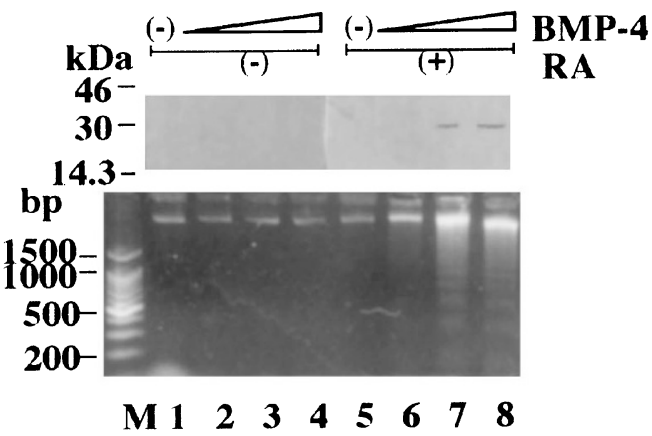

Figure 6 BMP-4 concentration required to induce the synergistic effects on the activation of caspase-9, Ac-DEVD-MCA cleavage activity and DNA fragmentation of $\mathrm{P} 19 \mathrm{EC}$ cells in the cooperation with RA. (A) Dose dependent effect of BMP-4 on AC-DEVD-MCA cleavage activity of P19 EC cells treated with (closed circles) and without (open circles) RA (1000 nM). (B) Dose dependent effect of BMP-4 on the processing of caspase-9 (upper panel) and DNA fragmentation (lower panel). Lane 1 and 5; without BMP-4, lane 2 and 6; with BMP-4 at $0.1 \mathrm{ng} / \mathrm{ml}$, lane 3 and 7 ; with BMP-4 at $1 \mathrm{ng} / \mathrm{ml}$, lane 4 and 8 ; with BMP-4 at $5 \mathrm{ng} / \mathrm{ml}$. Lane $1-4$; without RA and lane 5-8; with RA (1000 nM). M; size marker of DNA

the possibility that small amount of caspase- 9 was activated by undetectable amount of released cytochrome $\mathrm{c}$.

\section{Down-regulation of XIAP in the RA and BMP-4-treated P19 EC cells}

Neuronal apoptosis inhibitor protein (NIAP), a homologue of $\mathrm{XIAP}$, which is a candidate gene for type I spinal muscular atrophy (SMA), has an anti-apoptotic effect on apoptosis induced by a variety of signals, and it contributes to the SMA phenotype when deficient or absent. ${ }^{25}$ Very recently, XIAP has been shown to participate in the BMP signaling pathway as a positive regulator linking the BMP receptor and TAK1 and its activator, $\mathrm{TAB} .^{27}$ Activation of the BMP receptor by ligand binding elicits signals that induce not only ventralization but also apoptosis in Xenopus embryos through TAK1 activa-
A)

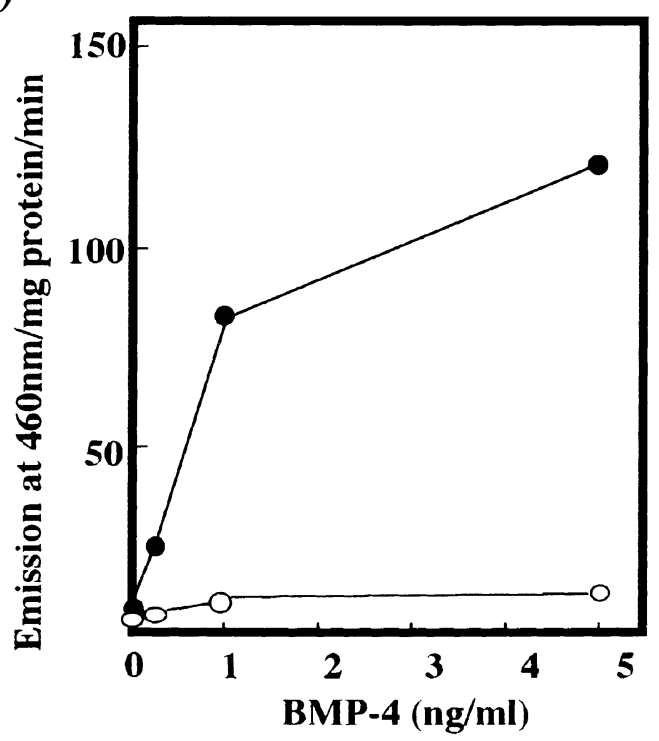

B)
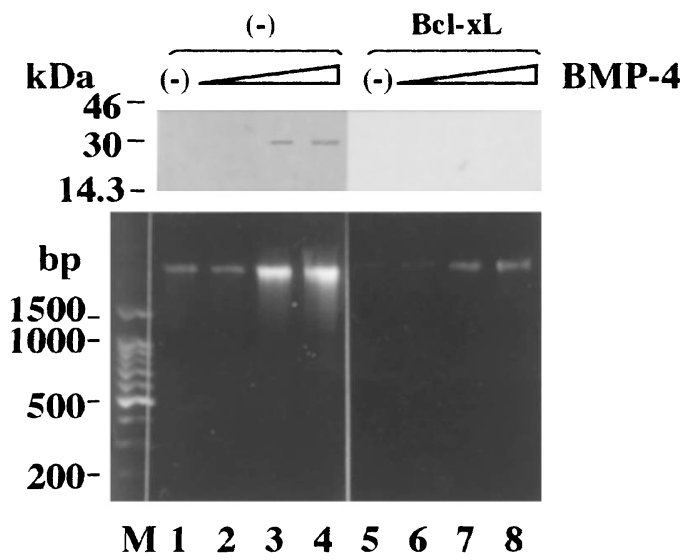

Figure 7 Inhibitory effects of Bcl-xL on the activation of caspase-9 and AcDEVD-MCA cleavage activity induced by RA and BMP-4 together. (A) AcDEVD-MCA cleavage activity in the RA/BMP-4-treated Bcl-xL-transformed and -nontransformed cells. Closed circles; nontransformed P19 EC cells; open circles, Bcl-xL-transformed cells. (B) The processing of caspase-9 (upper panel) and DNA fragmentation (lower panel) in the P19 EC cells simultaneously treated with RA $(1000 \mathrm{nM})$ and BMP-4 at different concentration. Lane 1-4, P19 EC cells; lane 5-8, Bcl-xL-transformed cells. Lane 1 and 5, RA-treated cells; lane 2 and 6, RA /BMP-4 $(0.1 \mathrm{ng} / \mathrm{ml})$-treated cells; lane 3 and 7 ; RA/BMP-4 ( $1 \mathrm{ng} / \mathrm{ml})$-treated cells; lane 4 and 8; RA/BMP-4 $(5 \mathrm{ng} / \mathrm{ml})$-treated cells. M; size marker of DNA

tion. $^{24}$ Overexpression of XIAP inhibits TAK1-induced apoptosis and promotes TAK1-induced ventralization, ${ }^{27}$ suggesting that XIAP is a key molecule regulating the apoptosis signals in the BMP receptor-TAK1 pathway. The level of XIAP may determine BMP-4-receptor-signal stimulation of the apoptotic pathway and the other signal pathways. The prominent decrease in the level of XIAP in the cytosol of the RA/BMP-4-treated apoptotic cells (Figure 8) may explain their synergistic effect on the activation of caspase-9. A small amount of caspase- 9 activated by RA via undetectable levels of released cytochrome $c$ or an unknown apoptotic pathway may induce the processing of a large amount of caspase- 9 in 
A)

B)

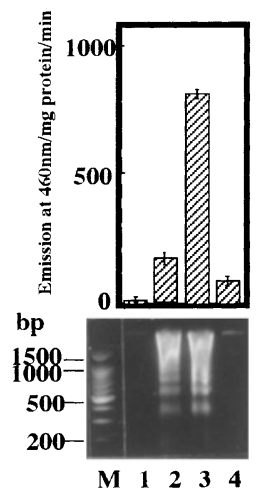

kDa

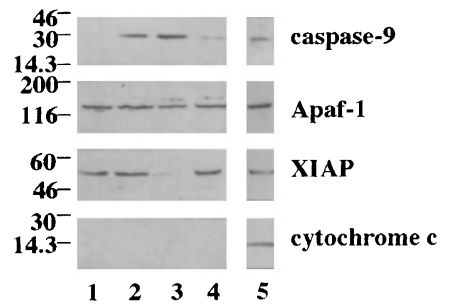

Figure 8 The level of XIAP and cytochrome $c$ in the apoptotic cells of the RA BMP-4-treated cells. (A) DNA fragmentation and Ac-DEVD-MCA cleavage activity in the cytosol fraction of the non-adherent cells and adherent cells of the RA and BMP-4-treated cells. Lane 1; untreated P19 EC cells, lane 2-4; total cells, non-adherent cells and adherent cells of the RA (1000 nM)/BMP-4 $(1 \mathrm{ng} / \mathrm{ml})$-treated P19 EC cells, respectively. (B) The level of processed fragment of caspase-9, Apaf-1, XIAP and cytochrome $c$ in the cytosol fraction of the apoptotic cells of the RA and BMP-4-treated cells. Lane 1; untreated P19 EC cells, lane 2-4; total cells, non-adherent cells and adherent cells of the RA/BMP-4-treated P19 EC cells, respectively, lane 5; total cells of staurosporine $(1 \mu \mathrm{M})$-treated P19 EC cells

cells, where XIAP is down-regulated by BMP-4 signals. Thus, activation of caspase- 9 may be regulated by a balance between apoptotic trigger signal molecules such as cytochrome $\mathrm{c}$ or unknown factors and protective factor molecules such as XIAP and members of the NIAP or Bcl-2 family.

\section{Molecular mechanism of RA and BMP-4 inducing synergistic effect on the activation of caspase-9}

The reason why BMP-4 alone cannot induce apoptosis and always requires RA synergistically is unclear. One possible explanation is that RA makes P19 EC cells competent to respond to BMP-4 signals or vice versa. BMP-4 receptors type I and type II were upregulated 2-fold in RA-treated cells (data not shown), suggesting that the upregulation of BMP-4 signals induces the synergistic effect of RA and BMP-4 on activation of caspase- 9 and apoptosis.

Msx-2, homeobox-containing gene, is one of the possible downstream targets of BMP-4-induced apoptosis signals. Msx-2 is expressed in the same regions in which BMP-4 induces cell death. Disruption of BMP-2 and -4 signaling by a dominant-negative BMP type I receptor prevents interdigital apoptosis and decreases of the Msx2 expression. ${ }^{4}$ Constitutive ectopic expression of Msx-2 in P19 EC cells markedly increases apoptosis induced upon aggregation. ${ }^{36}$ However, Msx-2 is not significantly upregulated by RA/BMP-4-treatment (Momoi, unpublished data).

Finally, we do not exclude the possibility that SMADs, the central effector molecules for BMP receptor signals, ${ }^{37}$ are involved in RA/BMP-4-induced apoptosis of P19 EC cells, since a dominant-negative mutation of SMAD inhibits processing of caspase-9 induced RA/BMP-4-treatment
(Momoi, unpublished data). A further study of the molecular mechanism by which the combination of BMP-4 and RA activates caspase- 9 and reduces the level of XAIP in the cytosol is currently underway.

\section{Materials and Methods}

\section{Cell culture}

P19 EC cells, originally established by McBurney et $a{ }^{6}{ }^{6}$ were kindly donated by Dr Hamada (Osaka University, Osaka, Japan). All experiments were performed with cells cultured as monolayer with RA (Sigma, St. Louis, MO, USA) and/or BMP-4 (R\&D Systems Inc., Minneapolis, MN, USA) unless otherwise noted. Non-adherent RA/BMP-4-treated cells were obtained by collecting the culture medium containing non-adherent cells. Adherent RA/BMP-4-treated cells were obtained by removing the non-adherent cells from the dishes by washing three times with phosphate-buffered saline (PBS).

\section{Ac-DEVD-MCA cleavage activity}

P19 EC cells were incubated with RA and/or BMP-4 for various periods. Ac-DEVD-MCA cleavage activity was measured as described previously. ${ }^{38}$ After incubation, cells were washed twice with PBS, and the cell pellets were lysed in PBS containing $0.2 \%$ Triton X-100 on ice for $10 \mathrm{~min}$. Cells were then centrifuged at $10000 \times g$ for $5 \mathrm{~min}$. To measure caspase-3-like activity the cell extracts (50 $\mu \mathrm{g}$ protein) were incubated with $10 \mu \mathrm{M}$ Ac-DEVD-MCA (Peptide Institute, Osaka, Japan), a synthetic peptide of the cleavage site of poly-ADP ribose polymerase, in incubation buffer (50 mM Tris- $\mathrm{HCl} \mathrm{pH} \mathrm{7.5,} 1 \mathrm{mM}$ dithiothreitol) at $37^{\circ} \mathrm{C}$ for $20 \mathrm{~min}$. The reactions were stopped by the addition of $10 \%$ sodium dodecyl sulfate (SDS). Fluorescence intensity was measured at $380 \mathrm{~nm}$ for excitation and at $460 \mathrm{~nm}$ for emission.

\section{Isolation of fragmented DNA}

DNA isolation was performed according to Prigent et al, ${ }^{39}$ with some modification. Cell pellets were lysed with $400 \mu$ of lysis buffer $(20 \mathrm{mM}$ Tris- $\mathrm{HCl}, \mathrm{pH} 7.4,20 \mathrm{mM}$ EDTA and 1\% Triton X-100). Lysis was allowed to proceed on ice for $10 \mathrm{~min}$, and the mixture was centrifuged for $10 \mathrm{~min}$ at $10000 \times \mathrm{g}$. The supernatant was digested with $50 \mu \mathrm{g} / \mathrm{ml}$ RNase A at $37^{\circ} \mathrm{C}$ for $1 \mathrm{~h}$. This was followed by proteinase $\mathrm{K}(50 \mu \mathrm{g} / \mathrm{ml})$ digestion at $37^{\circ} \mathrm{C}$ for $1 \mathrm{~h}$. After phenol-chloroform extraction, the DNA was precipitated by adding $2.5 \mathrm{vol}$ of $100 \%$ ethanol and $\mathrm{CH}_{3} \mathrm{COONa}$ (0.3 M final concentration). DNAs were separated on $1.8 \%$ NuSieve agarose (FMC Bioproducts, Rockland, ME, USA) gels.

\section{Transfection of caspase-9}

A full-length mouse caspase-9 cDNA was obtained from a cDNA library of RA-treated P19 EC cells (Stratagene, La Jolla, CA, USA). The CDNA was inserted into the EcoRl site of the pcDEF3 expression vector and transfected into P19 EC cells by the calcium-phosphate method. ${ }^{40}$ Eight hours after transfection in the presence or absence of Ac-DEVD-CHO $(10 \mu \mathrm{M})$, the transfected P19 EC cells were washed with cell culture medium and cultured again in the presence or absence of Ac-DEVD-CHO $(10 \mu \mathrm{M})$ for the indicated period.

P19 EC cells stably overexpressing Bcl-xL were obtained by transfection with pMKITNeo-bcl-xL and selection with G418 as described previously. ${ }^{41}$ 


\section{Immunoblot analysis}

Cells were lysed in PBS containing $0.2 \%$ Triton X-100. After centrifugation at $10000 \times \mathrm{g}$ for $10 \mathrm{~min}$, the cell extracts $(50 \mu \mathrm{g}$ protein) were subjected to SDS-acrylamide gel (12\%) electrophoresis. After transfer to nitrocellulose membranes, immunoreactivity was detected with anti-caspase-9 (I16), anti-XIAP, anti-Apaf-1 (MBL, Nagoya, Japan), and anti-cytochrome c (clone 7H8.2C2, Pharmingen, San Diego, CA, USA) antibodies and alkaline phosphataseconjugated goat anti-mouse or rabbit immunoglobulin (Promega, Madison, WI, USA).

\section{Assay for cytochrome $\mathbf{c}$ in the cytosol}

Cytosolic levels of cytochrome $c$ were examined according to the method of Rosse et al. ${ }^{42}$ P19 EC cells were treated with RA (1000 nM) and/or BMP-4 $(1 \mathrm{ng} / \mathrm{ml})$ for $24 \mathrm{~h}$ or staurosporine $(1 \mu \mathrm{M})$ for $5 \mathrm{~h}$ and then cells were collected by centrifugation. Cells pellets were homogenized in $200 \mu \mathrm{l}$ extraction buffer $(10 \mathrm{mM}$ HEPES buffer, $\mathrm{pH} 7.5,0.25 \mathrm{M}$ sucrose, $1 \mu \mathrm{g} / \mathrm{ml}$ leupeptin, $1 \mathrm{mM}$ phenylmethylsulfonyl fluoride), and the cytosol and membrane fractions including mitochondria were separated by centrifugation at $14000 \times g$ for $15 \mathrm{~min}$ at $4{ }^{\circ} \mathrm{C}$. Levels of cytochrome $\mathrm{c}$ were examined by immunoblot analysis as described above.

\section{Immunocytochemical staining of activated caspase-3}

RA and/or BMP-4-treated P19 EC cells were fixed with $2 \%$ paraformaldehyde for $15 \mathrm{~min}$. They were then incubated with anti-p20/17 antibody, an antiserum specific against activated caspase-3, as described previously. ${ }^{22,43}$ Immunoreactivity was detected by peroxidase-conjugated avidin-biotin kit (Vectastain $A B C$ kit, Vector Labs, Burlingame, CA, USA) and diaminobenzidine (DAB) (Sigma).

\section{References}

1. Yokouchi $Y$, Sakiyama J, Kameda T, Iba H, Suzuki A, Ueno N and Kuroiwa $A$ (1996) BMP-2/-4 mediate programmed cell death in chicken limb buds. Development 122: 3725-3734

2. Graham A, Heyman I and Lumsden A (1993) Even-numbered rhombomeres control the apoptotic elimination of neural crest cells from odd-numbered rhombomeres in the chick hindbrain. Development 119: 233-245

3. Graham A, Francis-West P, Brickell P and Lumsden A (1994) The signalling molecule BMP4 mediates apoptosis in the rhombencephalic neural crest. Nature 372: $684-686$

4. Zou H and Niswander L (1996) Requirement for BMP signaling in interdigital apoptosis and scale formation. Science 272: 738-741

5. Dupe V, Ghyselinck NB, Thomazy V, Nagy L, Davies PJA, Chambon P and Mark M (1999) Essential roles of retinoic acid signaling in interdigital apoptosis and control of BMP-7 expression in mouse autopods. Dev. Biol. 208: $30-43$

6. McBurney MW, Jones-Villeneuve EM, Edwards MK and Anderson PJ (1982) Control of muscle and neuronal differentiation in a cultured embryonal carcinoma cell line. Nature 299: 165-167

7. Slack RS, Skerjanc IS, Lach B, Craig J, Jardine Kand McBurney MW (1995) Cells differentiating into neuroectoderm undergo apoptosis in the absence of functional retinoblastoma family proteins. J. Cell Biol. 129: 779-788

8. Okazawa H, Shimizu J, Kamei M, Imafuku I, Hamada H and Kanazawa I (1996) $\mathrm{Bcl}-2$ inhibits retinoic acid-induced apoptosis during the neural differentiation of embryonal stem cells. J. Cell Biol. 132: 955-968

9. Glozak MA and Rogers MB (1996) Specific induction of apoptosis in P19 embryonal carcinoma cells by retinoic acid and BMP2 or BMP4. Dev. Biol. 179: $458-470$
10. Glozak MA and Rogers MB (1998) BMP4- and RA-induced apoptosis is mediated through the activation of retinoic acid receptor alpha and gamma in P19 embryonal carcinoma cells. Exp. Cell Res. 242: 165-173

11. Hengartner MO, Ellis RE and Horvitz HR (1992) Caenorhabditis elegans gene ced-9 protects cells from programmed cell death. Nature 356: 494-499

12. Yuan JY and Horvitz HR (1990) The Caenorhabditis elegans genes ced-3 and ced-4 act cell autonomously to cause programmed cell death. Dev. Biol. 138: $33-41$

13. Yuan JY and Horvitz HR(1992) The Caenorhabditis eleganscell death gene ced4 encodes a novel protein and is expressed during the period of extensive programmed cell death. Development 116: 309-320

14. Yuan JY, Shaham S, Ledoux S, Ellis HM and Horvitz HR (1993) The C. elegans cell death gene ced-3 encodes a protein similar to mammalian interleukin-1 betaconverting enzyme. Cell 75: 641-652

15. Jacobson MD, Weil M and Raff MC (1997) Programmed cell death in animal development. Cell 88: $347-354$

16. Thornberry NA and Lazebnik Y (1998) Caspases: Enemies within. Science 281: 1312-1316

17. Nicholson DW, Ali A, Thornberry NA, Vaillancourt JP, Ding CK, Gallant M, Gareau Y, Griffin PR, Labelle M, Lazebnik YA, Munday NA, Raju SM, Smulson ME, Yamin T-T, Yu VL and Miller DK (1995) Identification and inhibition of the ICE/CED-3 protease necessary for mammalian apoptosis. Nature 376: $37-43$

18. Li P, Nijhawan D, Budihardjo I, Srinivasula SM, Ahmad M, Alnemri ES and Wang X (1997) Cytochrome $c$ and dATP-dependent formation of Apaf-1/caspase- 9 complex initiates an apoptotic protease cascade. Cell 91: 479-489

19. Zou H, Henzel WJ, Liu A, Lutschg X and Wang X (1997) Apaf-1, a human protein homologous to $\mathrm{C}$. elegans CED-4, participates in cytochrome c-dependent activation of caspase-3. Cell 90: 405-413

20. Milligan CE, Prevette D, Yaginuma H, Homma S, Cardwell C, Fritz LC, Tomaselli KJ, Oppenheim RW and Schwartz LM (1995) Peptide inhibitors of the ICE protease family arrest programmed cell death of motoneurons in vivo and in vitro. Neuron 15: 385-393

21. Jacobson MD, Weil M and Raff MC (1996) Role of Ced-3/ICE-family proteases in staurosporine-induced programmed cell death. J. Cell Biol. 133: 1041-1051

22. Kouroku Y, Urase K, Fujita E, Isahara K, Ohsawa Y, Uchiyama Y, Momoi MY and Momoi T (1998) Detection of activated Caspase-3 by a cleavage site-directed antiserum during naturally occurring DRG neurons apoptosis. Biochem. Biophys. Res. Commun. 247: 780-784

23. Yamaguchi K, Shirakabe K, Shibuya H, Irie K, Oishi I, Ueno N, Taniguchi T, Nishida E and Matsumoto K (1995) Identification of a member of the MAPKKK family as a potential mediator of TGF-beta signal transduction. Science 270 : 2008-2011

24. Shibuya H, Iwata H, Masuyama N, Goto Y, Yamaguchi K, Irie K, Matsumoto K, Nishida $E$ and Ueno N (1998) Role of TAK1 and TAB1 in BMP signaling in early Xenopus development. EMBO J. 17: 1019-1028

25. Liston P, Roy N, Tamai K, Lefebvre C, Baird S, Cherton-Horvat, G, Farahani R, McLean M, Ikeda JE, MacKenzie A, Korneluk RG (1996) Suppression of apoptosis in mammalian cells by NAIP and a related family of IAP genes. Nature 379: $349-353$

26. Deveraux Q, Roy N, Stennicke HR, Arsdale TV, Zhou Q, Srinivasula SM, Alnemri ES, Salvesen GS and Reed JC (1998) IAPs block apoptotic events induced by caspase-8 and cytochrome $\mathrm{c}$ by direct inhibition of distinct caspases. EMBO J. 17: $2215-2223$

27. Yamaguchi K, Nagai S, Ninomiya-Tsuji J, Nishita M, Tamai K, Irie K, Ueno N, Nishida E, Shibuya H and Matsumoto K (1999) XIAP, a cellular member of the inhibitor of apoptosis protein family, links the receptors to TAB1-TAK1 in the BMP signaling pathway. EMBO J. 18: 179-187

28. Song Q, Mehler MF and Kessler JA (1998) Bone morphogenetic proteins induce apoptosis and growth factor dependence of cultured sympathoadrenal progenitor cells. Dev. Biol. 196: 119-127

29. Hu Y, Benedict MA, Wu D, Inohara N and Nunez G (1998) Bcl-XL interacts with Apaf-1 and inhibits Apaf-1-dependent caspase-9 activation. Proc. Natl. Acad. Sci. USA 95: 4386-4391

30. Pan G, O'Rourke K and Dixit VM (1998) Caspase-9, Bcl-XL, and Apaf-1 form a ternary complex. J. Biol. Chem. 273: 5841-5845

31. Kuida K, Haydar TF, Kuan CY, GuY, Taya C, KarasuyamaH, Su MS, Rakic P and Flavell RA (1998) Reduced apoptosis and cytochrome c-mediated caspase activation in mice lacking caspase-9. Cell 94: 325-337 
32. Hakem R, Hakem A, Duncan GS, Henderson JT, Woo M, Soengas MS, Elia A, de la Pompa JL, Kagi D, Khoo W, Potter J, Yoshida R, Kaufman SA, Lowe SW, Penninger JM and Mak TW (1998) Differential requirement for caspase-9 in apoptotic pathway in vivo. Cell 94: 339-352

33. Slee EA, Harte MT, Kluck RM, Wolf BB, Casiano CA, Newmeyer DD, Wang HG, Reed JC, Nicholson DW, Alnemri ES, Green DR and Martin SJ (1999) Ordering the cytochrome $c$-initiated caspase cascade: hierarchical activation of caspases-2,-3, -6, -7, -8, and -10 in a caspase-9-dependent manner. J. Cell Biol. 144: 281-292

34. Bossy-WetzelE, NewmeyerDD and Green DR(1998) Mitochondrial cytochrome c release in apoptosis occurs upstream of DEVD-specific caspase activation and independently of mitochondrial transmembrane depolarization. EMBO J. 17: $37-49$

35. Buckley CD, Pilling D, Henriquez NV, Parsonage G, Threlfall K, Scheel-Toellner D, Simmons DL, Akbar AN, Lord JM and Salmon M (1999) RGD peptides induce apoptosis by direct caspase-3 activation. Nature 397: 534-539

36. Marazzi G, Wang Y and Sassoon D (1997) Msx2 is a transcriptional regulator in the BMP4-mediated programmed cell death pathway. Dev. Biol. 186: 127-138

37. Massague J (1998) TGF-beta signal transduction. Annu. Rev. Biochem. 67 $753-791$.
38. Fujita E, Kouroku Y, Miho Y, Tsukahara T, Ishiura S and Momoi T (1998) Wortmannin enhances activation of CPP32 (Caspase-3) induced by TNF or antiFas. Cell Death Differ. 5: 289-297

39. Prigent P, Blanpied C, Aten J and Hirsch F (1993) A safe and rapid method for analyzing apoptosis-induced fragmentation of DNA extracted from tissues or cultured cells. J. Immunol. Methods 160: 139-140

40. Graham FL and van der Eb AJ (1973) A new technique for the assay of infectivity of human adenovirus 5 DNA. Virology 52: 456-467

41. Miho Y, Kouroku Y, Fujita E, Mukasa T, Urase K, Isoai A, Kasahara T, Momoi YM and Momoi T (1999) bFGF inhibits activation of caspase-3 and apoptosis of P19 embrypnal carcinoma cells during neuronal differentiation. Cell Death Differ. 6: $463-470$

42. Rosse T, Olivier R, Monney L, RagerM, Conus S, Fellay I, Jansen B and Borner C (1998) Bcl-2 prolongs cell survival after Bax-induced release of cytochrome c. Nature 391: $496-499$

43. Urase K, Fujita E, Miho Y, Kouroku Y, Mukasa T, Yagi Y, Momoi MY and Momoi T (1998) Detection of activated caspase-3 (CPP32) in the vertebrate nervous system during development by a cleavage site-directed antiserum. Dev. Brain Res. 111: $77-87$ 